\title{
Investigation of the Relationship between Physical Activity and Body Mass Index in Children with Down Syndrome
}

\author{
(1) Çiğdem El11, 回Esra Doğru Hüzmeli2, 回Özden Gökçek² \\ ${ }^{1}$ Hatay Mustafa Kemal University Faculty of Medicine, Department of Pediatrics, Hatay, Turkey \\ 2 Hatay Mustafa Kemal University, Health Science Faculty, Department of Physiotherapy and Rehabilitation, Hatay, Turkey
}

\begin{abstract}
Aim: This study aimed was to investigate the relationship between physical activity levels and the Body Mass index (BMI) of children with Down syndrome (DS).

Materials and Methods: This study included 26 children (15 male, 11 female) with DS. In this study, demographic information was recorded, the physical activity was measured with the Eurofit battery; body fat content, muscle weight, protein content, body fluid ratio and basal metabolic rate were measured by Bioelectric Impedance Analysis.

Results: The mean age of the participants was $10.96 \pm 2.94$ years and the mean BMI of the participants was $21.51 \pm 6.719$. There was moderate correlation between general fat weight and arm motion speed $(r=0,40)$; moderate correlation between sit and reach test and general fat weight $(r=-0.45)$, trunk fat weight $(r=-0.52)$, liquid ratio $(r=0.54)$; moderate correlation between basal metabolic rate and right hand grip strength $(r=0.73)$, right arm weight without fat $(r=0.70)$, right arm muscle weight $(r=0.69)$, basal metabolic rate $(r=0.73)$; left hand grip muscle with left arm muscle weight ( $r=0.74)$, left arm weight without fat $(r=0.75)$, basal metabolism rate $(r=0.72)$, mineral amount $(r=0.83)$, amount of protein $(r=0.83)$; moderate correlation between thirty-second shuttle and body fat percentage $(r=-0.44)$, liquid ratio $(r=0.45)$, body density $(r=0.46)$; moderate correlation between twisted arm hanging strength and fat rate in arm $(r=-0.47)$ with trunk fat rate $(r=-0.40)$, fat weight $(r=-0.39)$; moderate correlation between twenty-meter resistance and trunk fat rate $(r=-0.40)$.

Conclusion: It was seen that the physical activity level decreased as the fat ratio increased in individuals with DS. Basal metabolic rate, fluid ratio, and physical activity were found to be correlated.
\end{abstract}

Keywords: Eurofit battery, Down syndrome, bioelectric impedance analysis

\section{Introduction}

Down syndrome (DS) occurs due to the mosaicism, triploidy, or translocation of part or all of the $21^{\text {st }}$ chromosome. It is seen in one in every 700 live births (1). Individuals with DS lag in behind in terms of rough and fine motor skills compared to healthy individuals and fine motor skills are slower than their peers (2). It is seen that individuals with DS have a higher obesity prevalence than healthy individuals. Possible determinants of obesity include low levels of physical activity (3). Differences in various musculoskeletal and biological characteristics of individuals with DS, such as low muscle strength, growth retardation, and low running performance affect the number of participants inactivity $(4,5)$. These specifications cause low levels of physical activity (6). Low physical activity leads to being overweight 
or obese in children with DS (7). Reports from recent years suggest that there is a worldwide pandemic in terms of obesity and a sedentary lifestyle, which are risk factors for multiple negative health outcomes. Studies suggest that physical inactivity doubles health risks and brings a burden of disease compared to smoking, obesity, and hypertension and thus shortens the life span of those with this type of immobility in the middle age (8). Healthy children meet the needs of adequate physical activity by actively participating in daily play activities (9). However, children with disabilities such as DS cannot perform adequate physical activities (10). The aim of this study was to investigate the relationship between the physical activity level and Body Mass index (BMI) of children with DS.

\section{Materials and Methods}

This study was performed with individuals with DS who applied to the Pediatrics Outpatient Clinic of Hatay Mustafa Kemal University Health Application and Research Hospital. Permission was obtained from. The Mustafa Kemal University Ethics Committee. Consent was received from the parents and children. The demographic data of the patients was recorded and the body fat ratio, the fat content of the internal organs, bone weight, muscle weight, physical structure, body fluid ratio, and basal metabolic rate were determined. Physical activity was evaluated using the Eurofit battery. Inclusion criteria: those individuals with no serious cardiac problems, no cooperative problems, were included. Bioelectric Impedance Analysis: Bioelectrical impedance analysis was performed with the Tanita - BC 418 instrument. The device consists of a total of 8 electrodes, including two handgrips with anterior and posterior electrodes and four stainless steel rectangular electrodes on the soles of the feet attached to a metal platform placed on force page $4 / 12$ JournalAgent powered by LookUs transducers for weight measurement. Measurements are performed at $50 \mathrm{kHz}$ with a constant current of $0.8-\mathrm{mA}$ sine wave and the impedance on the tissues of the subjects is measured by the receiving electrodes for 5 separate zones (trunk, both arms, and both legs). Measurements took approximately 1-2 minutes for each volunteer and the detected values are output from the device. Bioelectric impedance was contained in the output from the analyzer; body weight, BMI, basal metabolic rate, body fat percentage, body fat mass, lean body mass, and total body water measurement data were recorded for evaluation (11-13).

Eurofit Test Battery: The Eurofit Test Battery, approved by the Council of Europe, was used to carry out 9 tests evaluating the flexibility, speed, endurance, and strength characteristics in approximately 45-60 minutes using simple equipment. This battery includes the following;

- flamingo balance test which is a single leg balance test;

- plate tapping-tests which measure the speed of limb movement;

- sit-and-reach-flexibility test (using $15 \mathrm{~cm}$ at the level of the feet);

- standing broad jump which measures explosive leg power;

- handgrip test which measures static arm strength;

- sit-ups in 30 seconds which measures trunk strength;

- bent arm hang which measures muscular endurance/ functional strength;

- 10x5-meter shuttle run which measures running speed and agility;

- 20 m endurance shuttle-run (bleep test) which measures cardiorespiratory endurance $(14,15)$.

\section{Statistical Analysis}

SPSS 20.0 version statistical program was used in the data analysis of our study. Statistical significance was evaluated at all levels of $p<0.05$. In this study, if Pearson Correlation test and parametric conditions were not provided, Spearman Correlation test was applied. Significance coefficients were defined as follows;

• 0.0-0.2 'very weak'

- 0.21-0.4 'weak'

• 0.41-0.6 'moderate'

• 0.61-0.8 'high'

• 0.81-1.0 'very high'.

\section{Results}

The clinical features of the patients are shown in Table I. According to Bioelectric Impedance Analysis data, 54\% of the patients had high weight, $27 \%$ had normal weight, and $19 \%$ had low weight (Figure 1). The Eurofit battery was found to have a negative correlation with sit and reach and 30-second shuttle parameters, body fat content, fat weight, and BMI. As the fat trunk, fat weight, and BMI increased, access to physical activity and access in the body decreased by thirty seconds. The plate tapping is negatively correlated with fat in general; a decrease in the plate tapping with an increase in fat in general. The bent arm hang parameter was found to be negatively correlated with a fat body, fat weight, and fat in the arm. Fat weight, fat in the arm, and the amount of fat in the trunk increased 
with decreasing bent arm hang. It was found that there was a negative correlation between the 20-meter durability and the fat body percentage, while the fluid ratio was correlated positively (Table II).

Handgrip strength was found to correlate positively with basal metabolic rate, lean arm mass, arm muscle mass, amount of mineral, and amount of protein. An increase in grip strength was observed as the mass of the lean arm and muscle mass of the arm increased (Table III).

\section{Discussion}

This study aimed was to investigate the relationship between physical activity levels and BMI children with DS. Physical activity was found to be related to basal metabolic rate, fluid ratio, amount of protein, fat, and muscle mass. Individuals with DS show more than 80 clinical features that may affect body fat and physical activity levels (16). Young people with DS have higher obesity and lower levels of physical fitness than their healthy peers, including those without DS but with intellectual disabilities (3). O'Shea et al. (17) evaluated the prevalence of obesity in children with DS by looking at the BMI of children between 4 and 16 years. They found $51.6 \%$ of males and $40 \%$ of females with DS have a high BMI. It was concluded that children with DS had higher obesity prevalence compared to the normal

Table I. Age, Body Mass index, liquid ratio, basal metabolic rate values of individuals $(x \pm S D)$

\begin{tabular}{|l|l|}
\hline Values & $\mathbf{X} \pm$ SD \\
\hline Age (years) & $10.96 \pm 2.94$ \\
\hline Body Mass index $\left(\mathbf{k g} / \mathbf{m}^{\mathbf{2}}\right)$ & $21.51 \pm 6.71$ \\
\hline Liquid ratio (\%) & $57.04 \pm 9.91$ \\
\hline Basal metabolic rate (Kcal) & $1.201 .48 \pm 667.18$ \\
\hline SD: Standard deviation & \\
\hline
\end{tabular}

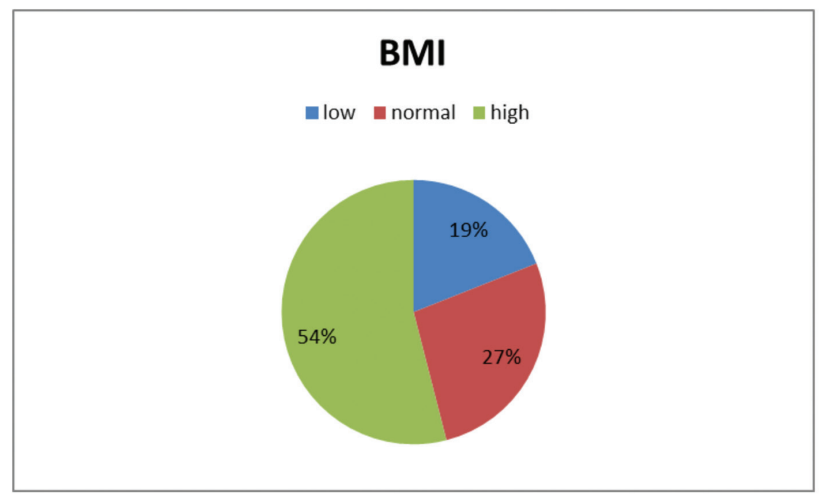

Figure 1. Body mass ratio BMI: Body Mass index population, which was associated with a higher body fat ratio. Similarly, in our study, $66.7 \%$ of males and $36.4 \%$ of females and $54 \%$ of the total had a high BMI. While Minck et al. (18) found no relationship between fitness components and obesity in individuals aged between 6 and 27 years, Pate et al. (19) found inconsistent results in the relationship between sitting and reach and obesity in boys and girls in individuals aged 6 to 18. In our study, a negative relationship was found between fat weight and sit and reach performance. The children who had high-fat weight were found to be less successful in the sit and reach than children with low-fat weight. Raudsepp et al. (20) found no relationship between fat and handgrip strength in prepubertal girls with obesity and balance. In this study, it was found that handgrip strength was correlated positively with basal metabolic rate, lean arm mass, arm muscle mass, amount of mineral, and amount of protein. An increase in grip strength was observed as the mass of the lean arm and muscle mass of the arm increased. Children with DS are more overweight or obese than the general population. The risk of obesity in children with DS increases after 2 years of age. Increased leptin, reduced resting energy consumption, comorbidities, inappropriate diet, and low levels of physical

Table II. Eurofit battery parameter with bioelectrical impedance analysis

\begin{tabular}{|c|c|c|c|}
\hline & Fat trunk & Fat weight & BMI \\
\hline \multicolumn{4}{|c|}{ Sit-and-reach $(\mathrm{cm})$} \\
\hline $\begin{array}{l}\text { r/rho } \\
\mathrm{p}\end{array}$ & $\begin{array}{l}-0.524 \\
0.006\end{array}$ & $\begin{array}{l}-0.466 \\
0.016\end{array}$ & $\begin{array}{l}-0.387 \\
0.051\end{array}$ \\
\hline \multicolumn{4}{|c|}{30 sec shuttle } \\
\hline \multirow[t]{2}{*}{$\begin{array}{l}\text { r/rho } \\
\mathrm{p}\end{array}$} & $\begin{array}{l}-0.489 \\
0.011\end{array}$ & $\begin{array}{l}-0.511 \\
0.008\end{array}$ & $\begin{array}{l}-0.438 \\
0.025\end{array}$ \\
\hline & Fat general & Fat arms & Muscle arms \\
\hline \multicolumn{4}{|c|}{ Plate tapping (sec) } \\
\hline \multirow[t]{2}{*}{$\begin{array}{l}\text { r/rho } \\
\mathrm{p}\end{array}$} & $\begin{array}{l}-0.407 \\
0.048\end{array}$ & $\begin{array}{l}-0.253 \\
0.212\end{array}$ & $\begin{array}{l}-0.050 \\
0.808\end{array}$ \\
\hline & Fat weight & Fat arms & Fat trunk \\
\hline \multicolumn{4}{|c|}{ Bent arm hang (sec) } \\
\hline \multirow[t]{2}{*}{$\begin{array}{l}\text { r/rho } \\
\mathrm{p}\end{array}$} & $\begin{array}{l}-0.395 \\
0.046\end{array}$ & $\begin{array}{l}-0.474 \\
0.014\end{array}$ & $\begin{array}{l}-0.402 \\
0.042\end{array}$ \\
\hline & Fat trunk \% & Liquid ratio & Fat leg \\
\hline \multicolumn{4}{|c|}{ 20-meter durability } \\
\hline $\begin{array}{l}\text { r/rho } \\
\mathrm{p}\end{array}$ & $\begin{array}{l}-0.408 \\
0.039\end{array}$ & $\begin{array}{l}0.396 \\
0.045\end{array}$ & $\begin{array}{l}-0.222 \\
0.275\end{array}$ \\
\hline
\end{tabular}


El et al.

Investigation of Physical Activity in Children with Down Syndrome

Table III. Eurofit battery parameter relation between hand grip strenght and bioelectrical impedance analysis data

\begin{tabular}{|c|c|c|c|c|c|}
\hline & $\begin{array}{l}\text { Basal metabolic } \\
\text { rate }\end{array}$ & $\begin{array}{l}\text { Lean arm mass } \\
\text { right }\end{array}$ & $\begin{array}{l}\text { Arm muscle } \\
\text { mass right }\end{array}$ & $\begin{array}{l}\text { Amount of } \\
\text { mineral }\end{array}$ & $\begin{array}{l}\text { Amount of } \\
\text { protein }\end{array}$ \\
\hline Handgrip strength right, $\mathrm{kg}$ r/rho & $\begin{array}{l}0.732 \\
0.000\end{array}$ & 0.700 & 0.692 & $\begin{array}{l}0.735 \\
0.000\end{array}$ & $\begin{array}{l}0.735 \\
0.000\end{array}$ \\
\hline & $\begin{array}{l}\text { Basal metabolic } \\
\text { rate }\end{array}$ & $\begin{array}{l}\text { Lean arm mass } \\
\text { left }\end{array}$ & $\begin{array}{l}\text { Arm muscle } \\
\text { mass left }\end{array}$ & Amount of mineral & $\begin{array}{l}\text { Amount of } \\
\text { protein }\end{array}$ \\
\hline Handgrip Strength left, kg r/rho & 0.727 & $\begin{array}{l}0.752 \\
0.000\end{array}$ & $\begin{array}{l}0.747 \\
0.000\end{array}$ & $\begin{array}{l}0.831 \\
0.000\end{array}$ & $\begin{array}{l}0.831 \\
0.000\end{array}$ \\
\hline
\end{tabular}

activity are causative factors of obesity (6). Bertapelli et al. (6) reported that physical activity has an effect on energy balance and that young people with DS who have low energy balance are more likely to be overweight or obese than those without DS. It shows that young people with DS have lower levels of physical activity than those without DS (3). A crosssectional study by Esposito et al. (21) evaluated 104 children with DS aged 8 to 16 and a weak relationship between physical activity and BMI and body fat ratio was found. In our study, the rate of fat, fat, and BMI increased, and 30-sec shuttle decreased. The increase in BMI showed an increase in the liquid ratio. Gomez et al. (22) reported in their cross-sectional study of 111 adolescents with DS aged 11 to 20 that the level of physical activity does not correlate with $\mathrm{BMI}$ and body fat ratio. Glover et al. (23) suggested that further research is needed to examine the effect of physical activity on BMI levels in young people. In our study, it was found that there was a decrease in plate tapping with an increase in general fat. Fat weight, fat in the arm, and the amount of fat in the trunk increased with a decrease in bent arm hang. In the literature, many studies are investigating the effects of physical activity on body composition, muscle strength, obesity, and the cardiovascular system. However, there are not enough studies examining BMI and physical activity levels in children with DS.

\section{Study Limitations}

The lack of a control group consisting of healthy children in the same age group is considered as the limitation of this study.

\section{Conclusion}

Most notably, it was seen that physical activity levels decreased as the fat ratio increased in individuals with DS. Basal metabolic rate, fluid ratio, and physical activity were found to be correlated.

\section{Ethics}

Ethics Committee Approval: This study was approved by Ethics Board of Mustafa Kemal University (approval number: 2017/150).

Informed Consent: All of the parents of the patients gave their informed consent prior to their child's inclusion in the study.

Peer-review: Enternally and internally peer-reviewed.

\section{Authorship Contributions}

Surgical and Medical Practices: E.Ç., E.D.H., Ö.G. Concept: E.Ç., E.D.H., Ö.G., Design: E.Ç., E.D.H., Ö.G., Data Collection or Processing: E.D.H., Ö.G., Analysis or Interpretation: E.D.H., Ö.G., Literature Search: E.Ç., E.D.H., Ö.G., Writing: E.Ç., E.D.H., Ö.G.

Conflict of Interest: None of the authors had conflict of interest.

Financial Disclosure: The authors declared that this study received no financial support.

\section{References}

1. Mégarbané A, Ravel A, Mircher $C$, et al. The 50th anniversary of the discovery of trisomy 21: the past, present, and future of research and treatment of Down syndrome. Genet Med 2009;11:611-6.

2. van Gameren-Oosterom HB, Fekkes M, Buitendijk SE, Mohangoo $A D$, Bruil J, Van Wouwe JP. Development, problem behavior, and quality of life in a population-based sample of eight-year-old children with Down syndrome. PLoS One 2011;6:e21879.

3. González-Agüero A1, Vicente-Rodríguez G, Moreno LA, GuerraBalic M, Ara I, Casajús JA. Health-related physical fitness in children and adolescents with Down syndrome and response to training. Scand I Med Sci Sports 2010;20:716-24.

4. Horvat M, Pitetti KH, Croce R. Isokinetic torque, average power, and flexion/extension ratios in nondisabled adults and adults with mental retardation. J Orthop Sports Phys Ther 1997;25:395-9.

5. Pitetti $\mathrm{KH}$, Fernhall B. Comparing run performance of adolescents with mental retardation, with and without Down syndrome. Article in Adapted physical activity quarterly: APAQ. 2004; 21: 219-228. 
6. Bertapelli F, Pitetti K, Agiovlasitis S, Guerra-Junior G. Overweight and obesity in children and adolescents with Down syndromeprevalence, determinants, consequences, and interventions: $\mathrm{A}$ literature review. Res Dev Disabil 2016;57:181-92.

7. Pitetti K, Baynard T, Agiovlasitis S. Children and adolescents with Down syndrome: physical fitness and physical activity. I Sport Health Sci 2013;2:47-57.

8. Hatch-Stein JA, Zemel BS, Prasad D, et al. Body Composition and BMI Growth Charts in Children With Down Syndrome. Pediatrics 2016;138. pii: e20160541.

9. Engel-Yeager B, Jarus T, Anaby D, Law M. Differences in patterns of participation between youths with cerebral palsy and typically developing peers. Am J Occup Ther 2009;63:96-104.

10. Jones DB. Denied from a lot of places' barriers to participation in community recreation programs encountered by children with disabilities in Maine: perspectives of parents. Leisure/ Loisir: Journal of the Canadian Association for Leisure Studies 2003;(28):49-69.

11. Andreacci LL, Dixon CB, Ledezma C, Goss FL. Effect of intermittent submaximal exercise on percent body fat using leg-to-leg bioelectrical impedance analysis in children. I Sports Sci Med 2006;5:424-30.

12. Sarıtaş N, Yıldız K, Hayta Ü. İlkokul Öğrencilerinin Bazı Motorik ve Fizyolojik Özelliklerinin Karşılaştırılması. CBÜ Beden Eğitimi ve Spor Bilimleri Dergisi 2017;12:117-27.

13. Telles S, Singh N, Bhardwaj AK, Kumar A, Balkrishna A. Effect of yoga or physical exercise on physical, cognitive and emotional measures in children: a randomized controlled trial. Child Adolesc Psychiatry Ment Health 2013;7:37.

14. Erikoğlu Ö, Güzel N, Pense M, Örer G. Comparison of Physical Fitness Parameters with EUROFIT Test Battery of Male Adolescent Soccer Players and Sedentary Counterparts. International Journal of Science Culture and Sport 2015;3:43-52.
15. Simşek E, Aktuğ ZB, Çelenk C, Yılmaz T, Top E, Kara E. The Evaluation of the Physical Characteristics of Football Players at the Age of 9-15 in Accordance With Age Variables. International Journal of Science Culture and Sport 2014;2:460-8.

16. Bull MJ. Committee on Genetics. Health supervision for children with Down syndrome. Pediatrics 2011;128:393-406.

17. O' Shea M, O' Shea C, Gibson L, Leo I, Carty C. The prevalence of obesity in children and young people with Down syndrome. I Appl Res Intellect Disabil 2018;31:1225-9.

18. Minck MR, Ruiter LM, Van Mechelen W, Kemper HCG, Twisk JWR. Physical fitness, body fatness, and physical activity: the Amsterdam Growth Study. Am J Hum Biol 2000;593-9.

19. Pate RR, Slentz CA, Katz DP. Relationships between skinfold thickness and performance of health-related fitness test items. Res Q Exerc Sport 1989;60:183-9.

20. Raudsepp L, Jurimae T. Physical activity, fitness, and adiposity of prepubertal girls. Pediatr Exerc Sci 1996;8:259-67.

21. Esposito PE, MacDonald M, Hornyak JE, Ulrich DA. Physical activity patterns of youth with Down syndrome. Intellect Dev Disabil 2012;50:109-19.

22. Izquierdo-Gomez R, Martínez-Gómez D, Villagra A, Fernhall B, Veiga OL; on behalf of the UP\&DOWN study group. Associations of physical activity with fatness and fitness in adolescents with Down syndrome: The UP\&DOWN study. Res Dev Disabil 2015;36C:428-36.

23. Glover WMC, O'Neill KL, Stettler N. Physical activity patterns in children with and without Down syndrome. Pediatr Rehabil 2006;9:158-64. 